\title{
Shariah Parameters on Islamic Exchange-Traded Fund (ETF) based on Gold and Silver: A Legal Perspective on the Liabilities of Shariah Advisers in Malaysia ${ }^{1}$
}

\author{
Abdullah Abdul Rahman*
}

\section{Introduction}

Gold and silver are ribawi items. Thus, any dealing with these items requires strict adherence to the Shariah principles governing ribawi transactions. Methods of dealing with gold and silver are clearly mentioned in many traditions of the Prophet (pbuh), inter alia:

"Don't sell gold for gold unless equal in weight, nor silver for silver unless equal in weight, but you could sell gold for silver or silver for gold as you like."2

Dealing in gold and silver without complying with the tenets of Shariah amounts to a usurious transaction, which is prohibited under Islamic law, as recorded in a narration:

"Gold is to be paid for by gold with equal weight, like for like, and silver is to be paid for by silver with equal weight, like for like. He who made an addition to it or demanded an addition dealt in usury." 3

The principle of trading in these two ribawi items is that the value or measurement of the items involved must be equal and its delivery must be on spot basis.

\section{Islamic ETF Based Gold and Silver in Malaysia: An overview}

On 7 October 2014, the Malaysian Securities Commission issued the 'Shariah Parameters on Islamic Exchange-traded Fund based on Gold and Silver' (Shariah Parameters) as guidance and reference from the Shariah perspective on matters relating to Islamic exchange-traded fund (ETF) based on gold and silver. The Shariah Parameter contains three parts. Part A consists of a general introduction to ribawi-based items and definitions while Part B outlines the Shariah requirements on trading in ribawi-based items. Part C, on the other hand, deals with the Shariah requirements for the Islamic ETF based on gold and silver. Essentially, Part C covers the Shariah tenets that must be complied with in establishing, structuring, and trading with an Islamic ETF Based on Gold and Silver. 
Paragraphs 4.02 and 4.03 of the Shariah Parameters requires the creation of Islamic ETF units based on gold and silver that are backed by physical gold and silver bullions or bars with specified quantity and quality. Thus, the units in an Islamic ETF, in total, represent the physical gold and silver bullions or bars held by the custodian on behalf of the Islamic ETF. Consequently, each Islamic ETF unit represents the unit holders' ownership of the gold and silver bullions or bars on a pro rata basis. In this regard, the Shariah Parameters requires the fund manager and the Shariah adviser of the Islamic ETF to verify that the gold and silver bullions or bars, with the correct quantity and quality as per the specification, are in existence and are allocated and segregated according to the Islamic ETF units as stated in Paragraph 4.03 of the Shariah Parameters. This indicates that since the transaction of ribawi-based items necessitates strict compliance with the principles of 'spot basis' delivery and equal value or measurement, the verification and ascertainment of the existence and accurate measurement of the gold or silver involved by the Shariah adviser is crucial. This scenario positions the Shariah adviser in a pivotal role for ensuring total Shariah compliance throughout the trading transaction.

\section{The Responsibilities of the Shariah Adviser}

The Shariah Parameters require the Shariah adviser of the Islamic ETF to, amongst other things, conduct an annual audit that includes a site visit to the place where the gold and silver bullions or bars are kept in order to confirm their existence, quantity and other details (such as a record of their movement). This is to ensure that the Islamic ETF units are backed by the actual gold and silver bullions or bars kept in the vault in a segregated and allocated manner. The Shariah Parameters also require the Shariah adviser of the Islamic ETF to prepare a report on the annual audit, to be included in the Shariah adviser's compliance report to the unit holders. ${ }^{4}$

Therefore, the requirements to conduct the annual site visit and to report to the unit holders on the outcome of the annual audit impose on the Shariah adviser the responsibility to confirm the details of the gold and silver backing the units. It is clear from the language of the Shariah Parameters that the confirmation by the Shariah adviser is intended to be relied on by the unit holders. Inevitably, this requires the Shariah adviser to possess expertise on gold and silver. For example, the Shariah adviser must be able to ascertain that the gold and silver kept in the vault is of the quality that the fund represents it to be. Any misrepresentation in the annual compliance report on the particulars of the gold and silver - for example, that they are of certain quality when they are not - may attract liabilities under the Capital Market and Services Act 2007 (CMSA). 


\section{The Liabilities of the Shariah Adviser}

Section 177 of the of the CMSA prohibits a person from making a statement or disseminating information that is false or misleading in a material particular and is likely to induce the sale or purchase of securities or is likely to have the effect of raising, lowering, maintaining or stabilising the market price of securities, if, when he makes the statement:

(a) he does not care whether the statement or information is true or false; or

(b) he knows or ought reasonably to have known that the statement or information is false or misleading in a material particular.

Under Section 179, a person who contravenes Section 177 commits an offence and shall be punished on conviction by imprisonment for a term not exceeding 10 years and to a fine of not less than RM1 million. Further, under Section 199 and Section 200, a person who has contravened Section 177 is also liable to civil actions by those who suffer loss or damage as a result thereof and by the Securities Commission respectively.

In this regard, the units in an Islamic ETF come within the definition of 'securities' under the CMSA. This is because under the CMSA, 'securities' are defined as including "shares in a body corporate" and "units in a unit trust scheme." The Exchange-Traded Funds Guidelines dated 11 June 2009, which also govern Islamic ETFs, defines ETF as "a listed index tracking fund structured as a unit trust scheme or any other approved structures whose primary objective is to achieve the returns that correspond to the performance of a particular index." Further, under the CMSA, 'unit trust scheme' is defined as any arrangement for the participation of persons as beneficiaries under a trust in profits or income arising from the acquisition, holding, management or disposal of securities. This would include an ETF as it involves investment in a basket of shares of companies within an index.

In ASC v McLeod (2000) 18 ACLC 424, a geologist was prosecuted in an Australian court under a provision similar to S. 177 of the CMSA in relation to a report for a listed mining company which predicted that a significant profit could have been earned from a diamond deposit based on the concentration of diamond to ore found in a small number of samples. The court held that what the person making the statement 'ought reasonably to have known' was to be determined by assessing the surrounding circumstances of the statement in the context of the person making it. The court found that the geologist ought to have known that the statement was misleading given that the sample size was small, the exploration programme was only in its early stages and the discovery of the particular type of 
diamond deposit was the first of its kind in Australia.

ASC v McLeod did not deal with the issue of whether the geologist did not care that the statement he made was true or not. It is more likely that this would arise where an expert provides confirmation beyond his field of expertise, rather than in a situation like ASC v McLeod where the expert ignored relevant considerations or took into account irrelevant considerations. In Malaysia, it remains to be seen whether a Shariah adviser who does not possess the requisite expertise to give confirmation on the particulars of gold and silver in the annual compliance report to the unit holders would be held to be acting without care as to whether his statement or information is true or false. It may be concluded that the Shariah parameters governing Islamic ETF based on gold and silver require due diligence on the part of the Shariah adviser who is appointed to carry out the task. A Shariah adviser who does not possess the requisite expertise would be exposed to a heavy statutory liability if he/she fails to act with due diligence.

\section{Notes}

* Abdullah Abdul Rahman is a partner (Dispute Resolution and Islamic Finance Divison) of Cheang \& Ariff in Kuala Lumpur. He can be contacted at abdullah@, cheangariff.com.

1. This paper is an expanded version of an article written by the author for Islamic Finance News, and published on 19th November 2014. The original title of the article was "Gold and Silver ETF: Shariah Advisers' Liabilities Under the Recent Shariah Pronouncement".

2. Sahih al-Bukhari Book 34, Hadith 125 , <http://sunnah.com/bukhari/34/125>, (accessed on August 15, 2016).

3. Sahih Muslim, Book 22, Hadith 107, <http://sunnah.com/bukhari/22/107>, (accessed on August 15, 2016).

4. See Paragraph 5.01-5.03 of the Shariah Parameter on Islamic ETF Based on Gold and Silver. 